\title{
The Effect of Online Customer Review on Trust and its impact on Purchase Intention in Cinema Films on Subscribers of YouTube Channel Review Film Cine Crib
}

\author{
Dwi Sanda Rahayu ${ }^{1}$, Farah Oktafani ${ }^{2}$ \\ \{dwisanda02@gmail.com ${ }^{1}$ \} \\ Telkom University, Indonesia
}

\begin{abstract}
This study is motivated by the phenomenon of Online Customer Review through Cine Crib as a YouTube channel movie review which is good for the advancement of the Indonesian movie as part of the Creative Industry. This study aims to determine The Effect of Online Customer Review on Trust and its impact on Purchase Intention in Cinema Films on subscribers of Cine Crib. This study uses a quantitative method type of descriptive and causal research. The sampling techniques in this study uses Non- probability sampling type of Purposive Sampling. The Population in this study are Cine Crib's subscribers with the number of the sample were 347 samples. Data analysis techniques used in this study are Descriptive Analysis and Path Analysis. Based on the result of Descriptive Analysis, overall Online Customer Review and Trust are in the excellent category, and Purchase Intention is in a good category. Based on the result of Path Analysis, Online Customer Review has a significant effect on Trust, Trust has a significant effect on Purchase Intention, Online Customer Review has a significant effect on Purchase Intention, and Online Customer Review has an indirect effect on Purchase Intention through Trust.
\end{abstract}

Keywords: Online Customer Review, Purchase Intention, Trust

\section{Introduction}

According to the survey results from Saiful Mujani Research and Consulting (SMRC) with the title "Who watched Cinema Films?" uploaded in 2019, an Indonesian Film genre that liked by young people as the most generation in Indonesia's current demographic structure is Comedy with a percentage of $70.8 \%$. While based on data uploaded by BEKRAF in a published report entitled "General View of the Indonesian Movie Industry 2019", the most genre that widely produced by various Indonesian film production houses is Drama with a percentage of $48 \%$. This shows the gap between the genre of film liked by the public with the genre of film produced. However, aside from this, the development of Indonesian films as part of the Creative Industry in the last 3 years still shows significantly improved results. This can be seen in the table 1 . 
Table 1. The advancement of Indonesian Movie

\begin{tabular}{|c|c|c|c|}
\hline Description & $\mathbf{2 0 1 7}$ & $\mathbf{2 0 1 8}$ & $\mathbf{2 0 1 9}$ \\
\hline Audience & 42.248 .908 & 51.192 .832 & 51.901 .745 \\
\hline Number of Movies & 112 & 128 & 129 \\
\hline
\end{tabular}

According to XXI Cinema Corporate Secretary Catherine Keng, The Film Industry began to grow in 2016 when the government released the film from the Negative Investment List. In addition, the existence of the internet can also be a factor that makes The Film Industry much increased. According to the Indonesian Internet Service Providers Association (APJII), accessing Social Media such as YouTube, Instagram, Facebook, Twitter, etc. Is the number one reason for using the internet in Indonesia, with a percentage of $19,1 \%$. In Indonesia, one of the most frequently used Social Media is YouTube with a percentage of $15.1 \%$. There are various videos in the YouTube application, one of them is the Indonesian Movie Review. Based on observations made by the author on 29th February 2019, there are three Channels of YouTube Movie Review in Indonesia with the most subscribers, namely Cine Crib, Daily Screen, and \#Sumatranbigfoot. Data comparison of the three Channels can be seen from the table 2 .

Table 2. Data Comparison of the YouTube review channels

\begin{tabular}{|c|c|c|}
\hline Name & Number of Subscribers & Number of Videos \\
\hline Cine Crib & 180.000 & 533 \\
\hline Daily Screens & 175.000 & 223 \\
\hline \#Sumatranbigfoot & 56.100 & 333 \\
\hline
\end{tabular}

Cine Crib is a Movie Review Channel on YouTube specializing in Indonesian films. The existence of Cine Crib enables Indonesian people to find complete information about Indonesian Films. Moreover, on January $1^{\text {st }} 2020$, Indonesia's largest illegal film streaming website named IndoXXI, was officially closed by the Ministry of Communication and Information Technology (Kominfo) to protect Intellectual Property Rights (cnbcindonesia.com). Therefore, people who want to watch movies inevitably have to visit the cinema if they do not want to wait for the film, they want to watch being shown on one of the tv stations in Indonesia in an indefinite time. The presence of a movie review YouTube channel is expected to overcome one of the problems that exist in the Film Industry, namely the desired genre of film with the genre of film produced which is not appropriate or match. That is because the film review channel can be a transparent forum for film lovers to find out the latest developments about Indonesian Films. Based on the results of the Pre-Questionnaire conducted by the author, it is known that Cine Crib has high trust from its subscribers so that the film review given affects the Purchase Intention in Cinema Films which is good for the advancement of the Indonesian Film Industry.

Seeing the positive development of the Indonesian Film Industry, the high number of users of Social Media such as YouTube, and the presence of Cine Crib as a YouTube Channel Movie Review, the authors are interested in conducting research that discusses the "The Effect of Online Customer Review on Trust and its Impact on Purchase Intention in Cinema Films on Subscribers of YouTube Channel Movie Review Cine Crib". 


\section{Literature Review}

\subsection{Online Customer Review}

According to Sutanto and Aprianingsih [1], Online Customer Review can be explained as emerging marketing and advertising communications that play an important role in the consumer purchasing process to identify and evaluate the products that they need. There are four important dimensions of Online Customer Review, namely Source Credibility, Quality of Review, Quantity of Review, and Review Valance.

\subsection{Trust}

Mowen and Minor [2] state that trust is all knowledge owned by consumers and all conclusions that consumers make about objects, attributes, and benefits. McKnight et al. [3] states that trust is built between parties who do not yet know each other both in interactions and transaction processes. Two important dimensions of consumer trust are Trusting Belief and Trusting Intention.

\subsection{Purchase Intention}

According to Priansa [4], Purchase Intention can be measured in various dimensions. In general, these dimensions are related to four main dimensions, namely Transactional Interest, Referential Interest, Preferential Interest, and Explorative Interest.

\subsection{Conceptual Framework}

Based on the literature review, the Conceptual Framework in this study can be seen from the figure 1 .

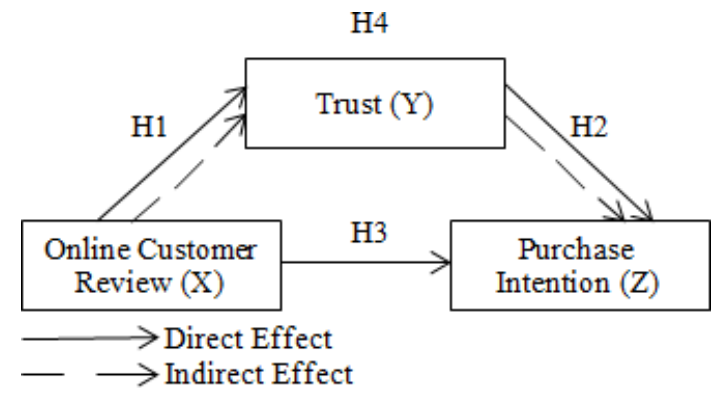

Fig. 1. Conceptual Framework.

\subsection{Hypothesis}

Based on Conceptual Framework Hypothesis for this study were:

a) Online Customer Review has a significant effect on Trust (H1).

b) Trust has a significant effect on Purchase Intention (H2).

c) Online Customer Review has a significant effect on Purchase Intention (H3). 
d) Online Customer Review has an indirect effect on Purchase Intention through Trust (H4).

\section{Research Methodology}

This study uses a quantitative method type of descriptive and causal research. The Sampling Technique in this study uses Non-probability Sampling type of Purposive Sampling. The Population in this study are 180.000 subscribers of Cine Crib. Based on Isaac and Michael Table with an error rate of $5 \%$, the number of samples in this study were 347 samples. The questionnaire that has been created distributed to respondents via google form to get data that will be processes in Descriptive Analysis and Path Analysis.

\section{Results and Discussion}

\subsection{Online Customer Review}

Based on the results of Descriptive Analysis, Online Customer Review (OCR) on subscribers of Cine Cribs is in the Excellent category at the $86.3 \%$ continuum line so it can be concluded that Cine Crib has implemented all four dimensions of the Online Customer Review variable namely Source Credibility, Quality Review, Quantity Review, and Review Valance very well. The statement "I believe that Cine Crib has watched the film that was reviewed before giving its review" got the highest score. Cine Crib divides four points of discussion in each review, namely Synopsis, Pros and Cons, Spoiler Talk, and Cine Score. In the Spoiler Talk section, Cine Crib reveals a general story of the film that cannot be obtained through synopsis or teaser films. This indicates that Cine Crib did watch the film before giving its review and it proves that Cine Crib is a trusted Movie Review Channel that could be used as a reference for subscribers to find information about the movie before watching Indonesian movie.

\subsection{Trust}

Based on the results of Descriptive analysis, Trust on Subscribers of Cine Crib is in the Excellent category at the $88.04 \%$ continuum line so it can be concluded that Cine Crib has implemented both dimensions of the Trust variable namely Trusting Belief and Trusting Intention Very Well. The statement "I believe that Cine Crib Reviewer has good intentions for the advancement of Indonesian Films" got the highest score. The words "We review movies weekly, all kinds of movies, especially Indonesian movies" written by Cine Crib on its YouTube Channel which indicates that Cine Crib cares about the progress of Indonesian Films, the number of Indonesian Film reviews by Cine Crib is more than the number of reviews Cine Crib for foreign films that can contribute to the advancement of Indonesian film. According to research conducted by Wijiharjono [5] which states that the key to successful film marketing is Genre, Symbols, Box Office, Director's Popularity, Producer Popularity, Budget, Aesthetic Quality, Advertising, expert views, awards, and word of mouth communication. Cine Crib through word-of-mouth communication, can be one of the keys to success for marketing film. 


\subsection{Purchase Intention}

Based on the results of Descriptive Analysis, Purchase Intention in Cinema Films on Subscribers of Cine Crib is in the Good category which is in the continuum line of $79.7 \%$ so it can be concluded that Cine Crib has implemented all four dimensions of Purchase Intention namely Transaction Interest, Referential Interest, Preferential Interest, and Explorative Interest well. The statement "I think Cine Crib can meet my needs for Information about Films" got the highest score. This is consistent with the facts that contained on the Cine Crib YouTube channel that they have reviewed various film genres and have produced hundreds of video reviews. Also, Cine Crib also began collaborating to make Ruang Casting the Series and Ngitus The Series with several other content creators so subscribers not only received movie review information, but also received information about how to make a scene in the movie. Cine Crib also makes several categories in addition to the one movie review, namely movie recommendations with favorite directors, monthly movie recommendations, series reviews, and best movie reviews according to Cine Crib's reviewers favorite, which can be seen in the Cine Crib playlist feature so that subscribers can easily find the information needed according available categories.

\subsection{The Effect of Online Customer Review on Trust}

Correlation Coefficient between Online Customer Review (OCR) Variables with Trust is 0.654 which indicates that there is a strong correlation between Online Customer Review (OCR) and Trust. The value of sig is 0,000 . That is smaller than the 0.05 as significance level so it can be concluded that there is a significant effect of Online Customer Review (OCR) on Trust so Hypothesis 1 is accepted. The path coefficient of the relationship between the Online Customer Review (OCR) with trust is 0.654 and the magnitude of the effect of Online Customer Review (OCR) on Trust based on the R square value is $42.8 \%$ while the remaining $57.2 \%$ is influenced by other variables that are not examined in this study.

This is in line with the reality that occurs on the YouTube Cine Crib Channel which in the comments column on the channel, subscribers can provide comments freely so that other subscribers can judge the honesties of Cine Crib reviewers by comparing it with comments given by fellow subscribers. The results of this study are following by result of the research by Kanitra and Kusumawati [6] entitled The Influence of Country of Origin and Online Consumer Review on Trust and Purchasing Decisions.

\subsection{The Effect of Trust on Purchase Intention}

The Correlation Coefficient value between Trust and Purchase Intention is 0.632 which indicates that there is a strong correlation between Trust and Purchase intention in Cinema Films on Subscribers of Cine Crib. The Significance Value of the Trust Variable is 0,000. That is smaller than the 0.05 as a significance level so it can be concluded that Trust has a significant effect on Purchase Intention so Hypothesis 2 is accepted. The path coefficient of the relationship between Trust and Purchase Intention is 0.334 and the magnitude of influence between Trust and Purchase Intention is $20.7 \%$ and the rest is influenced by other variables that are not examined in this study.

This can be proven from the results of the pre- questionnaire and the reality of the opinions of Cine Crib subscribers which can be seen in the comments column that subscribers state that they trust Cine Crib's review and the review provided can affect Purchase Intention 
Cinema Films. The results of this study are in line with the result of research by Farki, Baihaqi, and Wibawa [7] entitled The Effect of Online Customer Review and Rating on Trust and Purchase Intention in Online Marketplace in Indonesia, it is known that Trust in Online Review can influence Purchase Intention.

\subsection{The Effect of Online Customer Review on Purchase Intention}

The Correlation Coefficient between Online Customer Review (OCR) and Purchase Intention is 0.674 which indicates that there is a strong correlation between Online Customer Review (OCR) and Purchase Intention. The Significance Value of the Online Customer Review (OCR) is 0,000 . That is smaller than the 0.05 as a significance level, so it can be concluded that Online Customer Review (OCR) has a significant effect on Purchase Intention so Hypothesis 3 is accepted. The path coefficient of the relationship between Online Customer Review (OCR) with Purchase Intention is 0.455 and the magnitude of the influence of the Online Customer Review (OCR) on Purchase Intention is $11.2 \%$ and the rest is influenced by other variables not examined in this study.

This is in line with the reality of the posts uploaded by subscribers by mentioning Cine Crib as a reviewer that influences them in watching films, and some of their posts also include a score rating of the film that their watches based on Cine Crib's recommendations. The post was then re-uploaded by Cine Crib as proof that the review they gave influenced the audience's purchase intention in watching cinema films. The results of this study are in line with research conducted by Sinaga and Kusumawati [8] with the title The Effect of YouTube Beauty Vlogger on Consumer Purchase Intention and their impact on Product Purchasing Decisions known that YouTube Beauty Vlogger as an Online Customer Review (OCR) significantly influences Consumer Purchase Intention.

\subsection{Indirect effect of Online Customer Review on Purchase Intention through Trust}

Based on the results of research that has been processed, there is an indirect effect of Online Customer Review (OCR) on Purchase Intention through Trust so Hypothesis 4 is accepted. The Significance Value of Online Customer Review (OCR) and Trust Variables is 0,000 . This number is smaller than 0.05 as a significance level so that it can be concluded that the Online Customer Review (OCR) and Trust significantly influence the Purchase Intention. Online Customer Review (OCR) variable relationship path coefficient with Trust is 0.654 and Trust variable relationship path coefficient with the Purchase Intention variable is 0.334 . The results of calculations to determine the magnitude of the indirect effect of Online Customer Review (OCR) on Purchase Interest through trust is to multiply the two results of the path coefficients and the results obtained 0.218 so that it can be concluded that the magnitude of the indirect effect of Online Customer Review (OCR) on Purchase Intention through Trust is 0.218 or $21.8 \%$.

The results of this study are in line with the result of the research conducted by Mulyati and Gesitera [9] entitled The Effect of Online Customer Review (OCR) on Purchase Intention with Trust as an Intervening variable in Bukalapak Online Stores in Padang City which shows there are indirect effects between Online Customer Review (OCR) on Purchase Interest through Trust as an intervening variable. 
Here is the resume for the result of Path Analysis

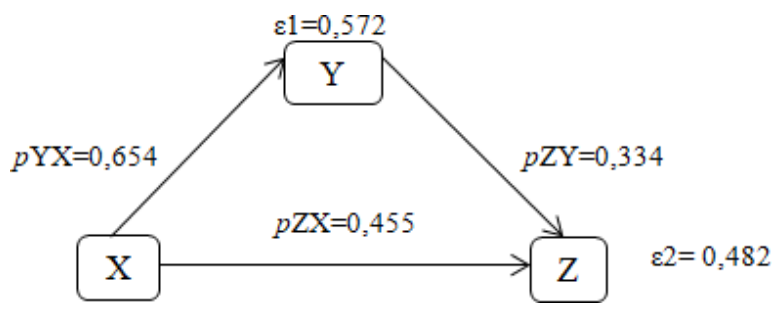

Fig. 2. Model Diagram of Path Analysis.

$$
\begin{array}{ll}
\text { Equation of Sub-structure 1: } & \mathrm{Y} 1=\mathrm{pYX}+\varepsilon 1 \\
& \mathrm{Y} 1=0,654 \mathrm{X}+0.428 \varepsilon 1 \\
\text { Equation of Sub-structure 2: } & \mathrm{Y} 2=\mathrm{pZX}+\mathrm{pZY}+\varepsilon 2 \\
& \mathrm{Y} 2=0,455 \mathrm{X}+0,334 \mathrm{Y}+0,482 \varepsilon 2
\end{array}
$$

\section{Conclusion}

This research aims to determine The Effect of Online Customer Review (OCR) on Trust and its Impact on Purchase Intention in Cinema Films on Subscribers of Cine Crib. Based on the research, it can be concluded that:

a) Based on the results of Descriptive Analysis, overall Online Customer Review (OCR) is in the Excellent category at the $86.3 \%$ continuum line so it can be concluded that Cine Crib has implemented all four dimensions of the Online Customer Review variable very well.

b) Based on the results of Descriptive Analysis, overall Trust is in the Excellent category at the $88.04 \%$ continuum line so it can be concluded that Cine Crib has implemented both dimensions of the Trust variable very well.

c) Based on the results of Descriptive Analysis, Purchase Intention in Cinema Films on Subscribers of Cine Crib is in the Good category which is in the continuum line of $79.7 \%$ so it can be concluded that Cine Crib has implemented all four dimensions of Purchase Intention well.

d) Based on the results of Path Analysis, it is known that Online Customer Review (OCR) has a Significant Effect on Trust of $42.8 \%$.

e) Based on the results of Path Analysis, it is known that Trust has a Significant Effect on Purchase Intention of $20,7 \%$.

f) Based on the results of Path Analysis, it is known that Online Customer Review (OCR) has a Significant Effect on Purchase Intention of $11,2 \%$.

g) Based on the results of Path Analysis, it is known that Online Customer Review (OCR) has an indirect effect on Purchase Intention through Trust of $21.8 \%$

\subsection{Suggestions}

a) Cine Crib can use its power to collaborate with the Indonesian Film Company Association (APFI) to make films that match with the wants of the public. 
b) Cine Crib is advised to invite its subscribers to have open discussions so Cine Crib can continue to maintain its existence as a trusted and loved movie reviewer.

c) Cine Crib is recommended to make educational content specifically about the achievements of Indonesian films both domestically and abroad.

d) BEKRAF starts involving film reviewers as a potential part of the advancement of Indonesian Movie.

e) BEKRAF can conduct surveys periodically to knows exactly what the community wants for Indonesian film.

f) Further research can examine the same object with the same variables, different objects with the same variables, same Research Object but with different Variables or use different or recent theories so that the results can be used to strengthen the results that there is a good impact film review on Indonesian Films.

\section{References}

[1] M. A. Sutanto and A. Aprianingsih, "The effect of online consumer review toward purchase intention: A study in premium cosmetic in Indonesia," in Journal International Conference on Ethics of Business, Economics, and Social Science, 2016, pp. 218-230.

[2] J. C. Mowen and M. Minor, Perilaku Konsumen, 5th ed. Jakarta, 2001.

[3] D. H. McKnight, V. Choudhury, and C. Kacmar, "The impact of initial consumer trust on intentions to transact with a web site: a trust building model," J. Strateg. Inf. Syst., vol. 11, no. 3-4, pp. 297-323, 2002.

[4] D. J. Priansa, "Komunikasi Pemasaran Terpadu,” Bandung: Pustaka Setia, 2017.

[5] N. Wijiharjono, "Kajian perkembangan penelitian pemasaran film," 2017.

[6] A. R. Kanitra and A. Kusumawati, "Pengaruh Country of Origin dan Online Consumer Review terhadap Trust dan Keputusan Pembelian (Survei Pada Mahasiswa S1 Fakultas Ilmu Administrasi Universitas Brawijaya Angkatan 2015/2016 dan 2016/2017 Tahun Akademik 2017/2018 Pembeli Produk Oppo Smartphon,” J. Adm. Bisnis, vol. 61, no. 1, pp. 64-73, 2018.

[7] A. Farki, "Pengaruh online customer review dan rating terhadap kepercayaan dan minat pembelian pada online marketplace di Indonesia.” Institut Teknology Sepuluh Nopember, 2016.

[8] R. E. M. Sinaga and A. Kusumawati, "Pengaruh youtube beauty vlogger terhadap minat beli konsumen dan dampaknya terhadap keputusan pembelian produk (studi pada pengguna kosmetik maybelline di indonesia),” J. Adm. Bisnis, vol. 63, no. 1, pp. 187-196, 2018.

[9] Y. Mulyati and G. Gesitera, "Pengaruh Online Customer Review terhadap Purchase Intention dengan Trust sebagai Intervening pada Toko Online Bukalapak di Kota Padang," J. Maksipreneur Manajemen, Koperasi, dan Entrep., vol. 9, no. 2, pp. 173-194, 2020. 